\title{
HIF-1 $\alpha$ Levels in patients receiving chemoradiotherapy for locally advanced non-small cell lung carcinoma
}

\section{SUMMARY}

AIM: To examine the relationship between treatment response and hypoxia-inducible factor-1 alpha (HIF-7 $\alpha)$ levels in patients with locally advanced non-small cell lung cancer (NSCLC) who received chemoradiotherapy (CRT).

METHODS: Eighty patients with NSCLC were included in the study and treated at Acibadem Mehmet Ali Aydinlar University Medical Faculty. HIF-1 a levels were measured before and after CRT by the enzyme-linked immunosorbent assay (ELISA) method.

RESULTS: Patients' stages were as follows; stage IIIA (65\%) and stage IIIB (35\%). Squamous histology was 45\%, adenocarcinoma was $44 \%$, and others were $11 \%$. Chemotherapy and radiotherapy were given concurrently to 80 patients. Forty-five (56\%) patients received cisplatin-based chemotherapy, and 35 (44\%) received carboplatin-based chemotherapy. Serum HIF-1a levels (42.90 $\pm 10.55 \mathrm{pg} / \mathrm{mL})$ after CRT were significantly lower than the pretreatment levels $(63.10 \pm 10.22 \mathrm{pg} / \mathrm{mL}, p<0.001)$ in patients with locally advanced NSCLC. CONCLUSION: The results of this study revealed that serum HIF-7 $\alpha$ levels decreased after CRT. Decrease of HIF-7 $\alpha$ levels after the initiation of CRT may be useful for predicting the efficacy of CRT.

KEYWORDS: Carcinoma, Non-Small-Cell Lung. Chemoradiotherapy. Hypoxia-Inducible Factor 1, alpha Subunit.

\section{INTRODUCTION}

Lung cancer is the primary cause of cancer deaths worldwide in both men and women'. Non-small cell lung cancer (NSCLC) elucidates most lung cancers (approximately 85\%)2. Treatment depends on the cell type (small cell versus non-small cell), the patient's overall medical condition, and the tumor stage in lung cancer. Stage III NSCLC comprises a diverse group of patients with dissimilarities in the extent and localization of disease ${ }^{3}$. For most patients with clinically evident N2 disease, the approach is concurrent chemoradiotherapy, using platinum-based chemotherapy plus full-dose radiotherapy (RT) ${ }^{4}$.

Lung cancer is characterized by hypoxia and inflammation. Hypoxia-inducible factor-1 alpha (HIF-1 $\alpha$ ) takes part in the initiation, appraisal, and prognosis of lung cancer, and starts metastasis and angiogenesis by the transcription of multiple genes ${ }^{5}$. HIF- $1 \alpha$ is related to the resistance to chemothera- 
peutic agents ${ }^{6}$. HIF-1 $\alpha$ plays a role in the formation of lung cancer according to cigarette smoking, and mechanisms that may be effective on this pathway at the cellular level in the prevention of oxidative damage are studied ${ }^{7,8}$. It is thought that an antimetastatic effect can be achieved by acting on this mechanism? 9

In recent years, some studies have suggested that HIF-1 $\alpha$ may be prognostic in lung cancer and be associated with tumor aggression ${ }^{10-12}$. It is thought to be related to chemo-resistance in patients with lung cancer $^{13}$. In the literature, it has been shown that hypoxia-persuaded glutamine metabolism is convoluted in drug resistance in lung cancer, and the hypoxia-induced expression of glutamate dehydrogenase (GDH) depends on the upregulation of HIF-1 $\alpha^{14}$. This could be reversed by the death domain-associated protein (Daxx), which negatively regulates hypoxia-persuaded cell invasion by inhibiting the HIF-1 $\alpha /$ Histone deacetylase 1 (HDAC1) /Slug pathway ${ }^{15}$.

Studies have found that hypoxia is the most common feature in the progression of all solid tumors, and thus it has become a central issue in tumor physiology and cancer treatment. Therefore, we wanted to examine the relationship between treatment response and HIF-1 $\alpha$ levels in patients with locally advanced lung cancer who received chemoradiotherapy (CRT).

\section{METHODS}

The serum samples of 80 NSCLC patients who were referred to the Acibadem Mehmet Ali Aydınlar University Medical Faculty, Department of Medical Oncology, and Pulmonary Diseases from May to November 2018 were obtained. All patients had histologically confirmed NSCLC diagnosis and had not received any treatment within the last six months. The staging was determined according to the American Joint Committee on Cancer (AJCC) and International Union against Cancer (UICC) staging systems. Stage IIIA and IIIB patients were included in the study; all had taken curative CRT. Patients with another malignancy, early and terminal stage disease, any hypoxic disease, such as diabetes and ischemic heart disease, any infection, and who had had surgery within the last six months were excluded.

Detailed clinical history, physical examination, and a series of biochemistry tests were done before the treatment phase. Those with the Eastern Cooperative Oncology Group (ECOG) performance status of 1 or less and appropriate blood chemistry tests received chemotherapy concurrently with radiotherapy. Chemotherapy and radiotherapy were given concurrently to 84 patients, of whom 45 (56\%) received cisplatin-based chemotherapy, and 35 (44\%) received carboplatin-based chemotherapy. Concurrent CT regimens were cisplatin $50 \mathrm{mg} / \mathrm{m}^{2}$ on days $1,8,29$, and 36 with etoposide $50 \mathrm{mg} / \mathrm{m}^{2}$ on days $1-5$ and 29-33; paclitaxel $50 \mathrm{mg} / \mathrm{m}^{2}$ weekly with carboplatin dose of area under the curve (AUC) 2 and, for non-squamous tumors, only cisplatin $75 \mathrm{mg} / \mathrm{m}^{2}$ on day 1 with pemetrexed $500 \mathrm{mg} / \mathrm{m}^{2}$ on day 1 , every 21 days for three cycles. All patients $(n=80)$ received a total radiation dose of at least 60 Gy (range 50-66 Gy) in 2.0 Gy daily fractions.

Blood samples were obtained from patients in the morning after 12 hours of fasting before the initiation of CRT and after one week of treatment completion. Medical histories of the patients were also recorded on the initiation of therapy. Serum samples were stored at $-80^{\circ} \mathrm{C}$ until final analyses were carried out.

Measurement of serum hypoxia-inducible factor-1 (HIF) levels

and Serum HIF-1a levels were measured using the sandwich-enzyme-linked immunosorbent assay method with the Human ELISA kit (Elabscience, Catalog Number: E-EL-H1277, Wuhan, Hubei Province, China). A preliminary experiment was conducted to verify the validity of plasma samples. The coefficients of intra- and inter-assay variation were $4.8 \%$ $(\mathrm{n}=15)$ and $6.1 \%(\mathrm{n}=15)$, respectively.

\section{Statistical analysis}

Statistical analysis was carried out using SPPS 21.0 software (SPSS Inc., Chicago, IL., USA). Continuous variables were categorized using median values as the cut-off point. For group comparison of categorical variables, One-way ANOVA or Chi-square tests were used, and Mann-Whitney U test or KruskallWallis tests were used for the comparison of continuous variables. All statistical tests were carried out two-sided, and a p-value $\leq 0.05$ was considered statistically significant.

\section{RESULTS}

The general data of the 80 NSCLC patients are shown in Table 1. The median age of the patients was 63 (45-79) years. Most of the patients were male 
TABLE 1. GENERAL CHARACTERISTICS AND TREATMENT MODALITIES OF NON-SMALL CELL LUNG CANCER (NSCLC) PATIENTS.

\begin{tabular}{|c|c|c|c|}
\hline Characteristic & $\begin{array}{l}\text { No. of } \\
\text { cases }(\%)\end{array}$ & $\begin{array}{l}\text { Plasma HIF-1 } \alpha \text { level } \\
(\mathrm{pg} / \mathrm{mL})(\text { Mean } \pm \text { SD) }\end{array}$ & $p$ \\
\hline \multicolumn{4}{|l|}{ Gender } \\
\hline Female & $18(23)$ & $62.56 \pm 11.30$ & $>0.05$ \\
\hline Male & $62(77)$ & $63.42 \pm 9.76$ & \\
\hline \multicolumn{4}{|l|}{ PS } \\
\hline 0 & $45(56)$ & $66.27 \pm 9.69$ & $>0.05$ \\
\hline 1 & $31(39)$ & $63.09 \pm 10.38$ & \\
\hline 2 & $4(5)$ & $61.75 \pm 0.83$ & \\
\hline \multicolumn{4}{|l|}{ cStage } \\
\hline IIIA & $52(65)$ & $63.00 \pm 9.72$ & $>0.05$ \\
\hline IIIB & $28(35)$ & $63.38 \pm 10.40$ & \\
\hline \multicolumn{4}{|l|}{ Histopathology } \\
\hline $\begin{array}{l}\text { Adenocarci- } \\
\text { noma }\end{array}$ & $35(44)$ & $61.25 \pm 9,12$ & $>0.05$ \\
\hline $\mathrm{SqCC}$ & $36(45)$ & $67.83 \pm 4.81$ & \\
\hline Other & $9(11)$ & $63.00 \pm 11.21$ & \\
\hline
\end{tabular}

NSCLC = Non-small cell lung cancer; $P S=$ performance status; $E C O G-P S=$ Eastern Cooperative Oncology Group PS; SqCC = squamous cell carcinoma; $c$ Stage = clinical stage; HIF-1 $\alpha=$ hypoxia-inducible factor-1 alpha.

FIGURE 1. CHANGES OF SERUM HYPOXIA-INDUCIBLE FACTOR-1 ALPHA (HIF-1A) LEVELS BEFORE AND AFTER CHEMORADIOTHERAPY IN PATIENTS WITH LOCALLY ADVANCED NON-SMALL CELL LUNG CANCER (NSCLC).

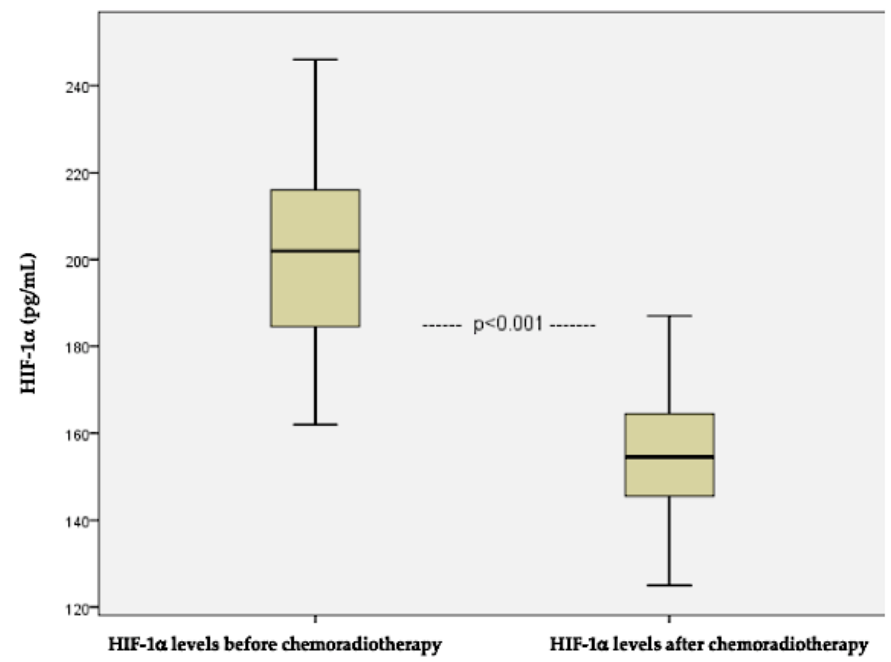

(77\%). Patients' stages were as follows: stage IIIA (35\%) and stage IIIB (65\%). Squamous histology was $45 \%$, adenocarcinoma was $44 \%$, and others were $11 \%$.

The changes in serum HIF-1 $\alpha$ levels before and after CRT in patients with locally advanced NSCLC are shown in Fig. 1. Serum HIF-1 $\alpha$ levels $(42.90 \pm 10.55$ $\mathrm{pg} / \mathrm{mL}$ ) after CRT were significantly lower than the pretreatment levels $(63.10 \pm 10.22 \mathrm{pg} / \mathrm{mL}, \mathrm{p}<0.001)$ in patients with locally advanced NSCLC.

\section{DISCUSSION}

Lung cancer is a highly lethal cancer worldwide. Although different treatments are available, the survival of patients is still poor. Oxygen supply is necessary for the growth of cells and is often diminished, especially inside the tumor mass in solid tumors. Tumor hypoxia contributes to radiotherapy- and chemotherapy-resistance of cancer cells, thus predicting an aggressive behavior by promoting neoangiogene$\operatorname{sis}^{16}$. The current study showed that serum HIF-1 $\alpha$ levels in patients with locally advanced NSCLC decreased significantly after CRT.

HIF-1 and HIF-2 coordinate the cellular response to hypoxia and are essential nuclear transcription factors for solid tumor growth and survival. When there is hypoxia, HIF-1 $\alpha$ heterodimerizes with the HIF-1 $\beta$ subunit within the tumor nucleus and binds to the hypoxia-response element (HRE). This way, HIF-1 stimulates several genes, such as erythropoietin or vascular endothelial growth factors (VEGFs), that are involved in angiogenesis, migration, and survival ${ }^{17,18}$. These genes are found to be explicated in tumor cells and are also involved in tumor progression $^{19}$. Tumor and endothelial cell-specific HIF1 $\alpha$ are found to have conflicting roles in thrombosis of cancer patients ${ }^{20}$. Furthermore, during lung injury due to sodium nitrite, antioxidants reverse this injury by downregulating HIF-1 $\alpha^{21}$.

In cervical and oropharyngeal carcinoma patients who are treated with radiotherapy, HIF-1a overexpression has been associated with poor outcome 22,23 . Hypoxia-induced resistance is multiplex. HIF-1 plays an important role in the conversion of cells into the hypoxic conditions, which precisely brings about the chemo-resistance of tumors ${ }^{24-33}$. Patients with shorter survival in early staged cancers are associated with overexpression of HIF-1 $\alpha^{34}$. Cisplatin and doxorubicin are the drugs for which hypoxia-induced drug resistance has been reported for lung cancer ${ }^{26}$. Furthermore, it has been shown that multidrug resistance in colon cancer can be reversed by HIF-1 inhibition ${ }^{35}$, and when compared with wild-types, HIF-1 $\alpha$ knockout cells are more sensitive to cytostatic and irradiation ${ }^{36}$.

Cancer stem cells (CSC) are thought as drivers of tumor growth and are responsible for unresponsiveness to therapy, recurrence, and metastasis. In hypoxia, CSCs are shown to be regulated by HIF$1 \alpha$ and HIF-2 $\alpha$ for survival and protection of tumor growth $^{37}$. The expression of a CSC marker which is called CD133, in both small cell lung cancer (SCLC) 
and NSCLC cells, was correlated with the hypoxia-induced up-regulation of HIF-1 $\alpha^{38}$. Moreover, $\mathrm{Hu}$ et al. $^{39}$ have tested F-fluoroerythronitroimidazole $\mathrm{PET} / \mathrm{CT}$ to evaluate the prognosis in NSCLC patients as an assessment for tumor hypoxia. A clinical study showed a decline in HIF-1 protein and mRNA levels in some of its target genes in tumor cells ${ }^{40}$. Additionally, Kummar et al. ${ }^{41}$ proved that a chemotherapy drug called topotecan decreases the expression of HIF-1 $\alpha$ and some HIF-1 genes in different solid tumors.

Furthermore, Zonta et et al. ${ }^{42}$ indicated that the regulatory signaling of melatonin is mediated via its receptor MT1, suggesting melatonin as an adjuvant strategy against angiogenesis in ovarian cancer (OC). Regarding reproductive cancers, overexpression of HIF-1a has also been linked to poor prognosis in OC, and treatment with melatonin reduced the levels of HIF-1 $\alpha$, VEGF, and VEGF receptor (VEGFR2).

He et al. ${ }^{43}$ have shown that the plasma HIF-1 $\alpha$ levels in NSCLC patients are higher than in healthy volunteers. The current research and this study all found that the plasma levels of HIF-1 $\alpha$ in NSCLC patients were higher than those of healthy people ${ }^{43}$. The reason for this might be that tumor tissues with high HIF-1 $\alpha$ protein expression experienced tissue necrosis, which resulted in a huge amount of HIF-1 $\alpha$ entering the bloodstream, or that there was a special regulation mechanism in the hematological system of NSCLC patients, such as CSCs ${ }^{43-49}$.

Since hypoxia is closely associated with chemoand radio-resistance, we investigated HIF-1a levels during CRT in patients with stage III NSCLC. We found that the levels of HIF-1a decrease during CRT. If these levels start to increase after CRT, following hypoxia and tumor progression, this means that HIF1a levels can be used to detect tumor progression and metastasis. Decreased HIF-1 $\alpha$ levels after the start of CRT may also be useful for predicting the efficacy of CRT. New hypotheses can be produced, and future studies are needed to prove this theory.

Conflict of interest: All authors declare no conflict of interest.

\section{RESUMO}

OBJETIVO: Examinar a relação entre a resposta ao tratamento e os níveis de fator 1 induzida por hipóxia (HIF-1 $\alpha$ ) em pacientes com câncer de pulmão de células não pequenas localmente avançado (NSCLC) que receberam quimiorradioterapia (CRT).

MÉTODO: Oitenta pacientes com NSCLC foram incluídos no estudo e foram tratados na Faculdade de Medicina da Acibadem Mehmet Ali Aydınlar University. O nível de HIF-1 $\alpha$ foi medido antes e depois da TRC pelo método de ensaio imunoenzimático (ELISA).

RESULTADOS: Os estágios dos pacientes foram os seguintes; estágio IIIA (65\%) e estágio IIIB (35\%). A histologia escamosa foi de 45\%, o adenocarcinoma de $44 \%$ e o outro de 11\%. Quimioterapia e radioterapia foram dadas simultaneamente a 80 pacientes. Quarenta e cinco (56\%) pacientes receberam quimioterapia à base de cisplatina e 35 (44\%) receberam quimioterapia à base de carboplatina. Os níveis séricos de HIF-7 $\alpha(42,90 \pm 10,55 \mathrm{pg} / \mathrm{mL})$ após a TRC foram significativamente menores do que os níveis pré-tratamento (63,10 $\pm 10,22 \mathrm{pg} / \mathrm{mL}, \mathrm{p}<0,001)$ em pacientes com NSCLC localmente avançado.

CONCLUSÃo: Os resultados deste estudo revelaram que os níveis séricos de HIF-7 $\alpha$ diminuíram após a TRC. A diminuição dos níveis de HIF-7 $\alpha$ após o início da TRC pode ser útil para prever a eficácia da TRC.

PALAVRAS-CHAVE: Carcinoma Pulmonar de Células não Pequenas. Quimiorradioterapia. Subunidade alfa do Fator 1 Induzível por Hipóxia.

\section{REFERENCES}

1. Torre LA, Bray F, Siegel RL, Ferlay J, Lortet-Tieulent J, Jemal A. Global cancer statistics, 2012. CA Cancer J Clin. 2015;65(2):87-108.

2. Silvestri GA, Gonzalez AV, Jantz MA, Margolis ML, Gould MK, Tanoue LT, et al. Methods for staging non-small cell lung cancer: diagnosis and management of lung cancer. $3^{\text {rd }}$ ed: American College of Chest Physicians evidence-based clinical practice guidelines. Chest. 2013;143(5 Suppl):e211S-50S.

3. Feinstein AR, Sosin DM, Wells CK. The Will Rogers phenomenon. Stage migration and new diagnostic techniques as a source of misleading statistics for survival in cancer. N Engl | Med. 1985;312(25):1604-8.

4. Pless M, Stupp R, Ris HB, Stahel RA, Weder W, Thierstein S, et al; SAKK Lung Cancer Project Group. Induction chemoradiation in stage IIIA/N2 non-small-cell lung cancer: a phase 3 randomised trial. Lancet. 2015;386(9998):1049-56.

5. Shah AA, Berry MF, Tzao C, Gandhi M, Worni M, Pietrobon R, et al. Induction chemoradiation is not superior to induction chemotherapy alone in stage IIIA lung cancer. Ann Thorac Surg. 2012;93(6):1807-12.
6. Deben C, Deschoolmeester V, De Waele J, Jacobs J, Van den Bossche J, Wouters $A$, et al. Hypoxia-induced cisplatin resistance in non-small cell lung cancer cells is mediated by HIF- $1 \alpha$ and mutant p53 and can be overcome by induction of oxidative stress. Cancers (Basel). 2018;10(4). pii: E126.

7. Lu L, Xu H, Yang P, Xue J, Chen C, Sun Q, et al. Involvement of HIF-1 $\alpha$-regulated miR-21, acting via the Akt/NF- $\mathrm{KB}$ pathway, in malignant transformation of HBE cells induced by cigarette smoke extract. Toxicol Lett. 2018;289:14-21

8. Li B, Li C, Zhu M, Zhang Y, Du J, Xu Y, et al. Hypoxia-induced mesenchymal stromal cells exhibit an enhanced therapeutic effect on radiation-induced lung injury in mice due to an increased proliferation potential and enhanced antioxidant ability. Cell Physiol Biochem. 2017;44:1295-10.

9. Yoshikawa Y, Takano O, Kato I, Takahashi Y, Shima F, Kataoka T. Ras inhibitors display an anti-metastatic effect by downregulation of lysyl oxidase through inhibition of the Ras-PI3K-Akt-HIF-1 $\alpha$ pathway. Cancer Lett. 2017:410:82-91. 
10. Wohlkoenig $C$, Leithner $K$, Olschewski A, Olschewski $H$, Hrzenjak A. TR3 is involved in hypoxia-induced apoptosis resistance in lung cancer cells downstream of HIF-1 $\alpha$. Lung Cancer. 2017;111:15-22.

11. Lin CS, Liu TC, Lee MT, Yang SF, Tsao TC. Independent prognostic value of hypoxia-inducible factor 1-alpha expression in small cell lung cancer. Int J Med Sci. 2017;14(8):785-90.

12. Yang N, Liang Y, Yang P, Ji F. Propofol suppresses LPS-induced nuclear accumulation of HIF-1 $\alpha$ and tumor aggressiveness in non-small cell lung cancer. Oncol Rep. 2017;37(5):2611-9.

13. Sowa T, Menju T, Chen-Yoshikawa TF, Takahashi K, Nishikawa S, Nakanishi $\mathrm{T}$, et al. Hypoxia-inducible factor 1 promotes chemoresistance of lung cancer by inducing carbonic anhydrase IX expression. Cancer Med. 2017;6(1):288-97.

14. Jiang $Z F$, Wang $M, X u J L$, Ning $Y$ J. Hypoxia promotes mitochondrial glutamine metabolism through HIF1 $\alpha-G D H$ pathway in human lung cancer cells. Biochem Biophys Res Commun. 2017;483(1):32-8.

15. Lin CW, Wang LK, Wang SP, Chang YL, Wu YY, Chen HY, et al. Daxx inhibits hypoxia-induced lung cancer cell metastasis by suppressing the HIF-1 $\alpha$ / HDAC1/Slug axis. Nat Commun. 2016;7:13867.

16. Tátrai E, Bartal A, Gacs A, Paku S, Kenessey I, Garay T, et al. Cell type-dependent $H I F 1 \alpha$-mediated effects of hypoxia on proliferation, migration and metastatic potential of human tumor cells. Oncotarget. 2017;8(27):44498-510

17. Semenza GL. Targeting HIF-1 for cancer therapy. Nat Rev Cancer. 2003;3(10):721-32

18. Semenza GL. HIF-1 mediates metabolic responses to intratumoral hypoxia and oncogenic mutations. J Clin Invest. 2013;123(9):3664-71.

19. Semenza GL. Hypoxia, clonal selection, and the role of HIF-1 in tumor progression. Crit Rev Biochem Mol Biol. 2000;35(2):71-103.

20. Evans $C E$, Bendahl PO, Belting M, Branco $C$, Johnson RS. Diverse roles of cell-specific hypoxia-inducible factor 1 in cancer-associated hypercoagulation. Blood. 2016;127(10):1355-60

21. Kadry MO, Ali HM. Downregulation of HIF1- $\alpha$, Smad-2, AKT, and Bax gene expression in sodium nitrite-induced lung injury via some antioxidants. Biochem Mol Toxicol. 2017;31(7).

22. Birner P, Schindl M, Obermair A, Plank C, Breitenecker G, Oberhuber G. Overexpression of hypoxia-inducible factor 1alpha is a marker for an unfavorable prognosis in early-stage invasive cervical cancer. Cancer Res. 2000;60(17):4693-6

23. Aebersold DM, Burri P, Beer KT, Laissue I, Djonov V, Greiner RH, et al. Expression of hypoxia-inducible factor-1alpha: a novel predictive and prognostic parameter in the radiotherapy of oropharyngeal cancer. Cancer Res. 2001;61(7):2911-6.

24. Brown LM, Cowen RL, Debray C, Eustace A, Erler JT, Sheppard FC, et al. Reversing hypoxic cell chemoresistance in vitro using genetic and smal molecule approaches targeting hypoxia inducible factor-1. Mol Pharmacol. 2006;69(2):411-8

25. Ravizza R, Molteni R, Gariboldi MB, Marras E, Perletti G, Monti E. Effect of HIF-1 modulation on the response of two- and three-dimensiona cultures of human colon cancer cells to 5-fluorouracil. Eur J Cancer 2009;45(5):890-8

26. Song X, Liu X, Chi W, Liu Y, Wei L, Wang X, et al. Hypoxia-induced resistance to cisplatin and doxorubicin in non-small cell lung cancer is inhibited by silencing of HIF-Talpha gene. Cancer Chemother Pharmacol. 2006;58(6):776-84.

27. Sullivan R, Paré GC, Frederiksen LJ, Semenza GL, Graham CH. Hypoxia-induced resistance to anticancer drugs is associated with decreased senescence and requires hypoxia-inducible factor-1 activity. Mol Cancer Ther. 2008;7(7):1961-73.

28. Hussein D, Estlin EJ, Dive C, Makin GW. Chronic hypoxia promotes hypoxia-inducible factor-1alpha-dependent resistance to etoposide and vincristine in neuroblastoma cells. Mol Cancer Ther. 2006;5(9):2241-50.

29. Liu L, Ning X, Sun L, Zhang H, Shi Y, Guo C, et al. Hypoxia-inducible factoralpha contributes to hypoxia-induced chemoresistance in gastric cancer. Cancer Sci. 2008;99(1):121-8.
30. Hao I, Song X, Song B, Liu Y, Wei L, Wang X, et al. Effects of lentivirus-mediated HIF-7alpha knockdown on hypoxia-related cisplatin resistance and their dependence on p53 status in fibrosarcoma cells. Cancer Gene Ther. 2008;15(7):449-55.

31. Huang L, Ao Q, Zhang Q, Yang X, Xing H, Li F, et al. Hypoxia induced paclitaxel resistance in human ovarian cancers via hypoxia-inducible factor 1alpha. I Cancer Res Clin Oncol. 2010;136(3):447-56.

32. Roberts DL, Williams KJ, Cowen RL, Barathova M, Eustace AJ, Brittain-Dissont $\mathrm{S}$, et al. Contribution of HIF-1 and drug penetrance to oxaliplatin resistance in hypoxic colorectal cancer cells. Br J Cancer. 2009;101(8):1290-7.

33. Sermeus A, Cosse IP, Crespin M, Mainfroid V, Longueville F, Ninane N, et al. Hypoxia induces protection against etoposide-induced apoptosis: molecular profiling of changes in gene expression and transcription factor activity. Mol Cancer. 2008;7:27.

34. Bertout JA, Patel SA, Simon MC. The impact of $\mathrm{O} 2$ availability on human cancer. Nat Rev Cancer. 2008;8(12):967-75.

35. Chen J, Ding Z, Peng Y, Pan F, Li J, Zou L, et al. HIF-1 $\alpha$ inhibition reverses multidrug resistance in colon cancer cells via downregulation of MDR1/P-Glycoprotein. PLoS One. 2014;9(6):e98882.

36. Rohwer N, Cramer T. Hypoxia-mediated drug resistance: novel insights on the functional interaction of HIFs and cell death pathways. Drug Resist Updat. 2011;14(3):191-201.

37. Heddleston JM, Li Z, Lathia JD, Bao S, Hjelmeland AB, Rich JN. Hypoxia inducible factors in cancer stem cells. Br J Cancer. 2010;102(5):789-95.

38. lida H, Suzuki M, Goitsuka R, Ueno H. Hypoxia induces CD133 expression in human lung cancer cells by up-regulation of OCT3/4 and SOX2. Int J Oncol. 2012;40(1):71-9.

39. Hu M, Xing L, Mu D, Yang W, Yang G, Kong L, et al. Hypoxia imaging with 18F-fluoroerythronitroimidazole integrated PET/CT and immunohistochemical studies in non-small cell lung cancer. Clin Nucl Med. 2013:38(8):591-6.

40. leong W, Rapisarda A, Park SR, Kinders RI, Chen A, Melillo G, et al. Pilot trial of EZN-2968, an antisense oligonucleotide inhibitor of hypoxia-inducible factor- 1 alpha (HIF-1 $\alpha$ ), in patients with refractory solid tumors. Cancer Chemother Pharmacol. 2014;73(2):343-8.

41. Kummar $S$, Raffeld $M$, Juwara L, Horneffer $Y$, Strassberger $A$, Allen $D$, et al. Multihistology, target-driven pilot trial of oral topotecan as an inhibitor of hypoxia-inducible factor-1 $\alpha$ in advanced solid tumors. Clin Cancer Res. 2011;17(15):5123-31.

42. Zonta YR, Martinez M, Camargo IC, Domeniconi RF, Lupi Júnior LA, Pinheiro PF, et al. Melatonin reduces angiogenesis in serous papillary ovarian carcinoma of ethanol-preferring rats. Int I Mol Sci. 2017;18(4). pii: E763.

43. He J, Hu Y, Hu M, Zhang S, Li B. The relationship between the preoperative plasma level of HIF-1 $\alpha$ and clinic pathological features, prognosis in nonsmall cell lung cancer. Sci Rep. 2016;6:20586.

44. Rong B, Liu Y, Li M, Fu T, Gao W, Liu H. Correlation of serum levels of HIF-1 $\alpha$ and IL-19 with the disease progression of COPD: a retrospective study. Int J Chron Obstruct Pulmon Dis. 2018;13:3791-803.

45. Xue L, Chen H, Lu K, Huang J, Duan H, Zhao Y. Clinical significance of changes in serum neuroglobin and HIF-1 $\alpha$ concentrations during the early-phase of acute ischemic stroke. J Neurol Sci. 2017;375:52-7.

46. Shao Y, Lv C, Yuan Q, Wang Q. Levels of Serum 25(OH)VD3, HIF-1 $\alpha$, VEGF, $\mathrm{VWf}$, and IGF-1 and their correlation in type 2 diabetes patients with different urine albumin creatinine ratio. J Diabetes Res. 2016;2016:1925424.

47. Peng J, Wang X, Ran L, Song J, Luo R, Wang Y. Hypoxia-inducible factor $1 \alpha$ regulates the transforming growth factor $\beta 1 / S M A D$ family member 3 pathway to promote breast cancer progression. | Breast Cancer. 2018;21(3):259-66.

48. Yu Q, Li L, Zhao N. Three-dimensional echocardiography in the diagnosis of myocardial infarction and its correlation with the expressions of serum HIF-1 $\alpha$, HO-1 and VEGF. Eur Rev Med Pharmacol Sci. 2018;22(9):2751-6.

49. Zhang F, Liu XL, Wang W, Dong HL, Xia YF, Ruan LP, et al. Expression of MMIF, HIF- $1 \alpha$ and VEGF in serum and endometrial tissues of patients with endometriosis. Curr Med Sci. 2018;38(3):499-504. 